\title{
Clavicular cortical hyperostosis: new autoinflammatory entity or part of the juvenile spondyloarthropathies clinical picture?
}

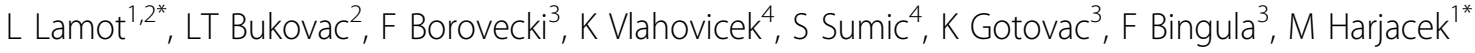 \\ From 18th Pediatric Rheumatology European Society (PReS) Congress \\ Bruges, Belgium. 14-18 September 2011
}

\section{Background}

Clavicular cortical hyperostosis $(\mathrm{CCH}$-variant of chronic recurrent multifocal osteomyelitis) is characterized by unilateral sterno-clavicular swelling. In adults, it is associated with spondyloarthropathies, but the possible association to juvenile spondyloarthropathies (jSpA) is currently unknown.

\section{Aim}

To identify genes with disease-specific expression patterns of patients diagnosed with $\mathrm{CCH}$ and healthy controls, and compared it to the jSpA patients.

\section{Patients and methods}

Peripheral blood samples of 5 new-onset, untreated patients with $\mathrm{CCH}, 11$ new-onset, untreated jSpA patients and 4 healthy controls were analyzed for expression patterns using Human Genome U133 PLUS 2.0 GeneChip, Affymetrix, (54675 probes). Processing of raw signal intensities and annotation of probesets was preformed. The RT-PCR was used to confirm differential gene expression in total of $9 \mathrm{CCH}, 11$ healthy controls and $32 \mathrm{jSpA}$ patients.

\section{Results}

Complex statistical analysis of gene expression patterns in patients with $\mathrm{CCH}$ identified 974 differentially expressed genes at statistical cutoffs fold change 1.5 $(\mathrm{p}<0.05, \max >100)$. Genes differentially expressed in patients with $\mathrm{CCH}$ were compared to the expression profiles of jSpA patients, and the analysis showed overlap in 282 genes.

\section{Conclusions}

$\mathrm{CCH}$ patients exhibit complex patterns of expression in genes related to inflammatory response (STAT3 downregulation), B-cell activation, MAP kinase (TRPM3 upregulation) chromatin modulation and transcription, cell death and apoptosis, and most interestingly, genes closely linked to autoinflammatory diseases (PTPN12 and MEFV). Additionally, profiles of patients with $\mathrm{CCH}$ and jSpA showed significant concordance in expression of genes linked to autoinflammatory (TLR-4, PTPN12) and autoimmune diseases (STAT3, CD36).

\section{Author details}

${ }^{1}$ Children's Hospital Srebrnjak, Division of Rheumatology. ${ }^{2}$ Department of Pediatrics, University of Zagreb School of Medicine, Zagreb, Croatia. ${ }^{3}$ Department for the functional genomics, Center for translational and clinical research, University of Zagreb School of Medicine, Zagreb, Croatia. ${ }^{4}$ Bioinformatics Group, Department of Molecular Biology, Faculty of Science, University of Zagreb, Zagreb, Croatia.

Published: 14 September 2011

doi:10.1186/1546-0096-9-S1-P299

Cite this article as: Lamot et al: Clavicular cortical hyperostosis: new autoinflammatory entity or part of the juvenile spondyloarthropathies clinical picture? Pediatric Rheumatology 2011 9(Suppl 1):P299.

* Correspondence: miroslav.harjacek@zg.t-com.hr

'Children's Hospital Srebrnjak, Division of Rheumatology

Full list of author information is available at the end of the article

(c) 2011 Lamot et al; licensee BioMed Central Ltd. This is an open access article distributed under the terms of the Creative Commons 